\title{
Relapsed Intravascular Large B-cell Lymphoma in the Lungs
}

\author{
Jung Yong Hong, M.D., Moon Ki Choi, M.D., Kyung Hee Kim, M.D., \\ Eun Jeong Joo, M.D., Jun Ho Jang, M.D., Kyung Soo Lee, M.D. ${ }^{1}$, \\ Young Hyeh Ko, M.D. ${ }^{2}$ and Won Seog Kim, M.D. \\ Departments of Medicine, ${ }^{1}$ Radiology, ${ }^{2}$ Pathology, Samsung Medical Center, \\ Sungkunkwan University School of Medicine, Seoul, Korea
}

\begin{abstract}
Intravascular lymphoma (IVL) is a rare form of non-Hodgkin's lymphoma that is characterized by the preferential growth of malignant lymphocytes within blood vessels. Pulmonary presentation of IVL is uncommon, and only a few cases have been reported in Korea. Here, we report on a 59-year-old woman with relapsed intravascular large B-cell lymphoma in the lungs. She had been treated with 6 cycles of rituximab, cyclophosphamide, adriamycin, vincristine, and prednisolone (R-CHOP) combination chemotherapy for intravascular large B-cell lymphoma in the nasal cavity, and was followed up regularly with no evidence of disease recurrence. About 1 year later, her chest computed tomography showed extensive ground-glass opacity, suggesting interstitial lung disease and, interestingly, diffuse pulmonary fluorodeoxyglucose (FDG) uptake was observed in positron emission tomography (PET). We performed bronchoscopy, bronchoalveolar lavage, and transbronchial lung biopsy. Pathology revealed relapsed intravascular large B-cell lymphoma in the lungs, and she commenced ifosfamide, methotrexate, etoposide, prednisolone (IMVP-16/PD) salvage chemotherapy. After 3 cycles of chemotherapy, PET showed no abnormal FDG uptake. We suggest that a primary or relapsed pulmonary IVL should be considered in the differential diagnosis of unexplained interstitial lung disease and that PET appears be useful in evaluating pulmonary IVL. (Korean J Hematol 2008;43:113-117.)
\end{abstract}

Key Words: Intravascular lymphoma, Interstitial lung disease, Positron emission tomography

\section{INTRODUCTION}

Intravascular lymphoma (IVL) is a rare form of non-Hodgkin's lymphoma that is characterized by proliferation of malignant lymphocytes within the lumina of small to medium-sized vessels. ${ }^{1)}$ The sites most commonly involved are the central nervous system, skin, and bone marrow. ${ }^{2,3)}$ Pulmonary presentation of IVL has been docu-

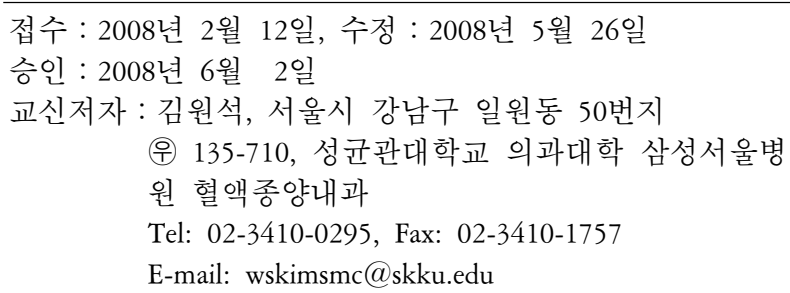

mented in a few cases. The major clinical symptoms include fever, cough, dyspnea, and loss of body weight, but these are not diagnostic. Most patients with pulmonary IVL show nonspecific radiological findings, including diffuse interstitial infiltrates, pleural effusion, signs of pulmonary hypertension, and tumor-like consolidation in the lungs. ${ }^{4-8)}$ The usefulness of positron emission tomography (PET) in diagnosing IVL has not been established, but Odawara et al. and

\footnotetext{
Correspondence to: Won Seog Kim, M.D.

Division of Hematology-Oncology, Department of Medicine, Samsung Cancer Center, Sungkyunkwan University School of Medicine

50, Ilwon-dong, Gangnam-gu, Seoul 135-710, Korea

Tel: +82-2-3410-0295, Fax: +82-2-3410-1757

E-mail: wskimsmc@skku.edu
} 
Hofman et al. suggested recently that PET is useful for evaluating IVL., ${ }^{9,10)}$

Here, we report on a 56-year-old woman with relapsed IVL in the lungs who showed extensive interstitial infiltrates in chest computed tomography (CT) and, interestingly, diffuse pulmonary high fluorodeoxyglucose (FDG) uptake in PET.

\section{CASE REPORT}

A 59-year-old woman presented with progressive dyspnea and cough lasting several weeks. Two years previously, she had been diagnosed with IVL in the nasal cavity (Ann Arbor stage III). After 6 cycles of rituximab, cyclophosphamide, adriamycin, vincristine, and prednisolone (R-CHOP) combination chemotherapy, she had shown a complete response in her follow-up head and neck CT, and subsequent periodic head and neck CT, chest CT, and abdomen-pelvis CT showed no evidence of recurrent disease.

She was admitted for further evaluation of progressive dyspnea. On admission, her blood pressure was $120 / 74 \mathrm{mmHg}$, pulse $108 / \mathrm{min}$, and body temperature $36.4^{\circ} \mathrm{C}$. Physical examination showed the patient to be acutely ill. There were no palpable cervical lymph nodes. Her breathing sound was coarse, and dry crackle was audible at both

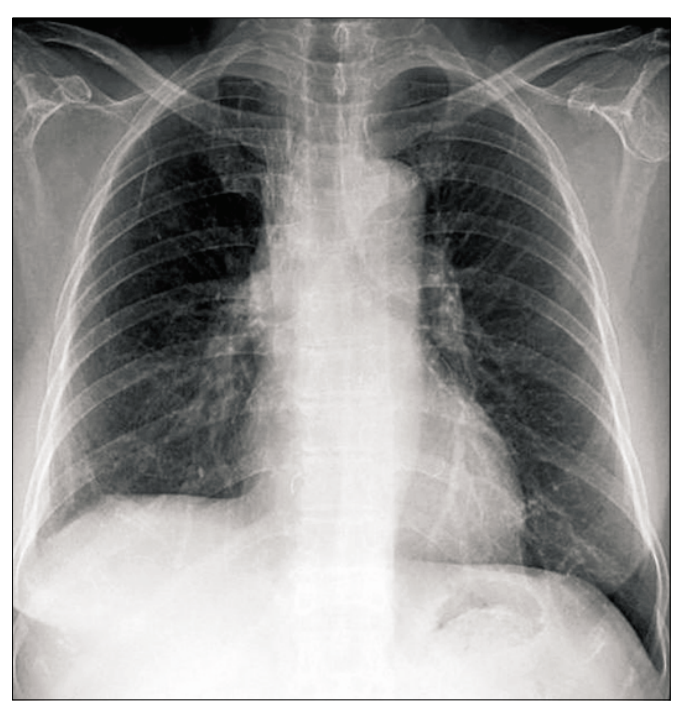

Fig. 1. Linear atelectasis in the right lower lung zone. lung fields on auscultation. Initial laboratory findings included white blood cell count, $3.21 \times$ $10^{9} / \mathrm{L}$ (segmented neutrophils, 79\%); hemoglobin level, $12 \mathrm{~g} / \mathrm{dL}$; erythrocyte sedimentation rate, $9 \mathrm{~mm} / \mathrm{h}$; serum C-reactive protein level, $0.08 \mathrm{mg} /$ $\mathrm{dL}$; and serum lactic dehydrogenase level, 1375 IU/L. Blood chemistry and electrolytes showed no abnormal findings, but arterial blood gas drawn in room air showed $\mathrm{PaO}_{2}, 39.2 \mathrm{mmHg}$; $\mathrm{PaCO}_{2}, 21.1 \mathrm{~mm} / \mathrm{Hg} ; \mathrm{pH} 7.50$; bicarbonate, 16.2 $\mathrm{mmol} / \mathrm{L}$; and $\mathrm{O}_{2}$ saturation, $81 \%$. Tests for pneumococcal and legionella antigen in the urine were negative, and tests for mycoplasma and cytomegalovirus (CMV) serology in the serum were negative. Chest X-ray showed linear atelectasis in the right lower lung zone (Fig. 1), and chest CT revealed extensive ground-glass opacity, suggesting interstitial lung disease process in both lungs (Fig. 2).

Supplemental oxygen therapy and broad-spectrum antibiotic treatment was started on suspicion of pneumonia. We planned bronchoscopy, bronchoalveolar lavage (BAL), transbronchial lung biopsy (TBLB), and PET to evaluate further the diffuse interstitial infiltrates in both lungs. Interestingly, PET demonstrated diffuse FDG uptake

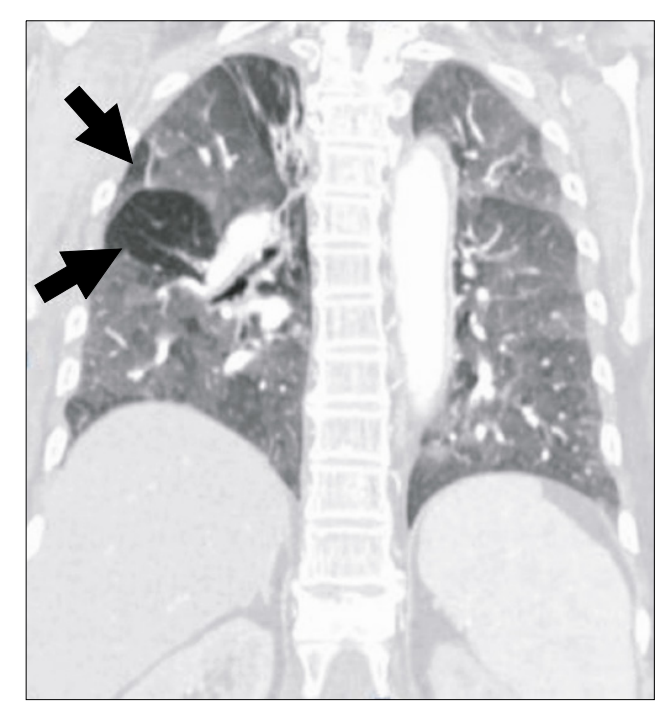

Fig. 2. Lung window of a coronal reformatted CT scan shows extensive ground-glass opacity in both lungs except for some areas (arrows). Ground-glass opacity lesions suggest the presence of interstitial disease process. 


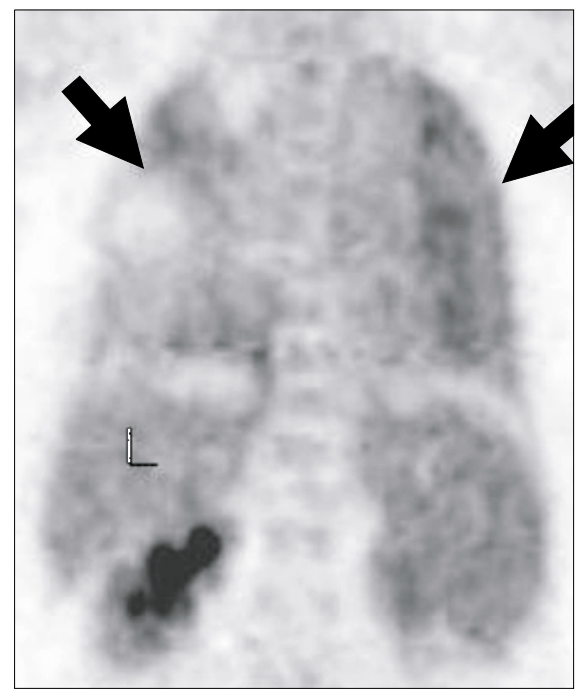

Fig. 3. Maximum intensity projection image of PET demonstrates diffuse FDG uptake in both lungs (arrows). Abbreviation: L, liver.

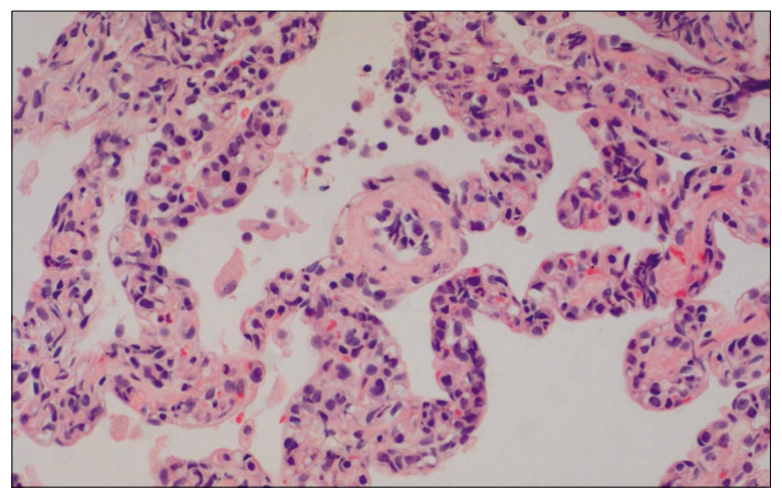

Fig. 4. Small and medium-sized blood vessels of the lung filled with intravascular lymphoma cells. Hematoxylin and eosin staining, $\times 400$.

in both lungs (Fig. 3). She was transferred to the medical ICU for bronchoscopy, BAL, and TBLB. The bronchoscopic examination showed no endobronchial lesion, and BAL was performed in the right middle lobe and TBLB in the right lower lobe, laterobasal segment. Gram stain and culture, Acid-fast bacilli stain and culture, and viral cultures for herpes simplex virus, cytomegalovirus, respiratory syncytial virus, adenovirus, and influenza virus in the BAL fluid were negative. Finally, TBLB pathology showed atypical lymphocyte proliferation in the small and medium-sized blood vessels (Fig. 4); the lympho-

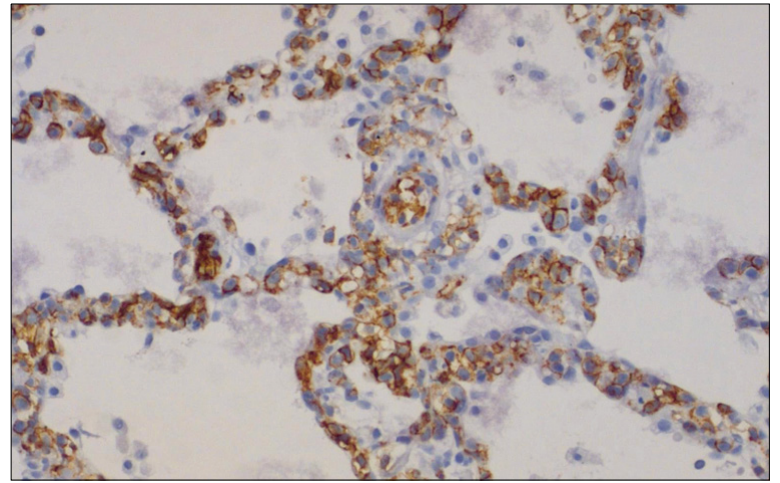

Fig. 5. Immunohistochemical staining for CD20 in neoplastic cells, $\times 400$.

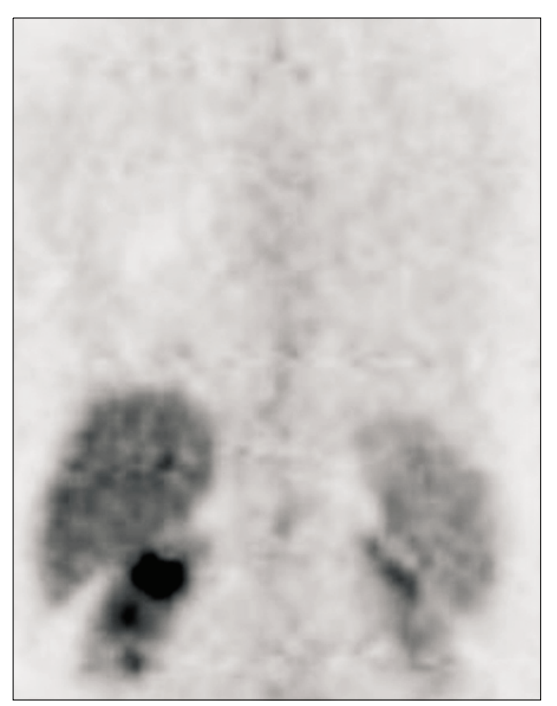

Fig. 6. Follow-up PET scan shows reduced lung lesions with nearly complete disappearance of FDG.

cytes were positive for CD20 in immunohistochemistry (Fig. 5). The final diagnosis was consistent with relapsed IVL in the lungs. Bone marrow examination also showed intravascular large B-cell lymphoma involvement.

Ifosfamide, methotrexate, etoposide, and prednisolone (IMVP-16/PD) salvage chemotherapy was started, and her dyspnea was gradually alleviated. The patient was discharged after chemotherapy and supportive care of neutropenia. At the time of discharge, her dyspnea had been dramatically reduced and there was no need for supplemental oxygen therapy. We performed 3 cycles of IMVP-16/PD chemotherapy and reevaluated 
using PET. The follow-up PET showed no abnormal FDG uptake in either lung, and both lungs showed a complete metabolic response (Fig. 6).

\section{DISCUSSION}

IVL is a rare form of non-Hodgkin's lymphoma that is characterized by the presence of lymphoma cells within the lumina of small to mediumsized vessels, and it has a highly variable end-organ involvement and clinical presentation. ${ }^{1)}$ IVL is aggressive and often takes a fatal clinical course. ${ }^{11,12)}$ The B-cell immunotype is most common, although cases with T-cell lineage have been reported. ${ }^{13,14)}$

IVL patients diagnosed in Western countries show a relatively high frequency of central nervous system and skin involvement, ${ }^{2)}$ whereas patients in Asian countries are more likely to show hemophagocytic syndrome, bone marrow involvement, fever, hepatosplenomegaly, and thrombocytopenia. ${ }^{3)}$ Pulmonary involvement of IVL is also rare. Only a few cases have been reported in Korea, and these have involved nonspecific radiological findings, including diffuse interstitial infiltrates, pleural effusion, signs of pulmonary hypertension, and tumor-like consolidation in the lungs. ${ }^{4-8)}$ No PET images of pulmonary IVL have been reported. Interestingly, two recent reports suggest that PET is useful for evaluating IVL. ${ }^{9,10}$ Odawara et al. reported a patient with disseminated IVL and high FDG uptake throughout the entire body on PET. Their patient received R-CHOP combination chemotherapy and showed a complete metabolic response on the follow-up PET. ${ }^{9)}$ Hofman et al. also showed that PET was useful in the early diagnosis of relapsed meningeal IVL, and the early diagnosis allowed prompt salvage chemotherapy. ${ }^{10)}$ Our patient is the first reported case of relapsed pulmonary IVL showing diffuse pulmonary FDG uptake on PET and a complete metabolic response after IMVP16/PD combination chemotherapy.

In conclusion, we suggest that primary or re- lapsed pulmonary IVL should be considered in the differential diagnosis of unexplained interstitial lung disease, and that PET could be useful in the diagnosis, staging, and early diagnosis of disease recurrence in pulmonary IVL.

\section{요 약}

혈관내 림프종은 비호지킨 림프종의 드문 한 종 류로 혈관내 악성 림프구의 증식을 특징으로 한다. 현재까지 한국에서 혈관내 림프종의 폐 침범은 매 우 드물게 보고되었다. 저자들은 혈관내 $\mathrm{B}$ 대세포 림프종이 폐로 재발한 59세 여자환자의 증례를 보 고한다. 환자는 비강에 발생한 혈관내 $\mathrm{B}$ 대세포 림 프종에 대하여 6차례의 cyclophosphamide, adriamycin, vincristine, prednisolone (R-CHOP) 복합항암요 법 후 완전관해로 추적관찰 중이었다. 항암치료 1년 경과 후 시행한 추적관찰 흥부 전산화 단층촬영에 서 간질성 폐질환을 시사하는 간유리 혼탁화 소견 이 보이고, 양전자방출단층촬영술에서 미만성 폐섭 취가 나타났다. 기관지 내시경, 폐 세척술, 경 기관 지 폐생검을 시행하였다. 폐조직검사 결과에서 재 발성 혈관내 $\mathrm{B}$ 대세포 림프종이 진단되었으며, 3 차 례의 ifosfamide, methotrexate, etoposide, prednisolone (IMVP-16/PD) 구제 항암요법을 시행하 였다. 구제항암요법 후 양전자방출단층촬영술에서 관찰되었던 미만성 폐섭취는 완전히 소실되었다. 저자들은 원인불명의 간질성 폐질환의 감별진단으 로 원발성 혹은 재발성 혈관내 $\mathrm{B}$ 대세포 림프종이 포함되어야 하며, 폐에 발생하는 혈관내 림프종을 평가하는데 양전자방출단층촬영술이 유용할 수 있 음을 제안한다.

\section{REFERENCES}

1) Ponzoni M, Ferreri AJ, Campo E, et al. Definition, diagnosis, and management of intravascular large B-cell lymphoma: proposals and perspectives from an international consensus meeting. J Clin Oncol 2007;25:3168-73.

2) Ferreri AJ, Campo E, Seymour JF, et al. Intravascular lymphoma: clinical presentation, natural history, management and prognostic factors in a series of 38 cases, with special emphasis on the 'cutaneous variant'. Br J Haematol 2004;127:173-83. 
3) Murase T, Nakamura S, Kawauchi K, et al. An Asian variant of intravascular large B-cell lymphoma: clinical, pathological and cytogenetic approaches to diffuse large B-cell lymphoma associated with haemophagocytic syndrome. Br J Haematol 2000;111:82634.

4) Aouba A, Diop S, Saadoun D, et al. Severe pulmonary arterial hypertension as initial manifestation of intravascular lymphoma: case report. Am J Hematol 2005;79:46-9

5) Chan VL, Lee CK, Leung WS, Lin SY, Chu CM. A 57-year-old woman with fever and abnormal chest CT findings. Chest 2006;130:924-7.

6) Gabor EP, Sherwood T, Mercola KE. Intravascular lymphomatosis presenting as adult respiratory distress syndrome. Am J Hematol 1997;56:155-60.

7) Ko YH, Han JH, Go JH, et al. Intravascular lymphomatosis: a clinicopathological study of two cases presenting as an interstitial lung disease. Histopathology 1997;31:555-62.

8) Yousem SA, Colby TV. Intravascular lymphomatosis presenting in the lung. Cancer 1990;65:349-53.

9) Odawara J, Asada N, Aoki T, et al. 18F-Fluorodeoxy- glucose positron emission tomography for evaluation of intravascular large B-cell lymphoma. $\mathrm{Br} \quad \mathrm{J}$ Haematol 2007;136:684.

10) Hofman MS, Fields P, Yung L, Mikhaeel NG, Ireland R, Nunan T. Meningeal recurrence of intravascular large B-cell lymphoma: early diagnosis with PET-CT. Br J Haematol 2007;137:386.

11) Bouzani M, Karmiris $T$, Rontogianni D, et al. Disseminated intravascular B-cell lymphoma: clinicopathological features and outcome of three cases treated with anthracycline-based immunochemotherapy. Oncologist 2006;11:923-8.

12) Ferreri AJ, Campo E, Ambrosetti A, et al. Anthracycline-based chemotherapy as primary treatment for intravascular lymphoma. Ann Oncol 2004;15:1215-21.

13) Mori S, Itoyama S, Mohri N, et al. Cellular characteristics of neoplastic angioendotheliosis. An immunohistological marker study of 6 cases. Virchows Arch A Pathol Anat Histopathol 1985;407:167-75.

14) Zuckerman D, Seliem R, Hochberg E. Intravascular lymphoma: the oncologist's "great imitator". Oncologist 2006;11:496-502. 